\title{
The synergistic effect of Zeolites type (A) with chlorinated rubber as flame retardants for unsaturated polyester resin
}

\author{
Jalil R. Ugal * Zahraa Q. Mahdi*
}

Received 20, December, 2012

Accepted 5, February, 2014

\begin{abstract}
:
In this work, the synergistic effect of chlorinated rubber (additive I), with zeolite 3A (additive II), zeolite 4A (additive III), and zeolite 5A (additive IV) in (1:1) weight percentage, on the flammability for unsaturated polyester resin was studied in the weight ratios for $(3,7,10,13 \& 15 \%)$ by preparing films of $(130 \times 130 \times 3) \mathrm{mm}$ in diameters. Three standard test methods used to measure were the flame retardation which are; ASTM: D-2863, ASTM: D- 635\& ASTM: D-3014.

Results obtained from these tests indicated that all of the additives were effective additive IV has the highest efficiency as a flame retardant.
\end{abstract}

Keywords: Flame Resistance; Zeolite; Additives; Composite materials; unsaturated polyester

\section{Introduction:}

Polymers had found many applications and added greatly to the quality of modern day life. However, a major problem arises because most of the polymers on which these materials are based are organic and thus flammable. In the UK alone some 800-900 deaths and roughly 15000 injuries result from fire each year [1].

Flame retardants comprise a diverse group of chemicals which are widely used at relatively high concentrations in many applications, including the manufacture of electronic equipments, textiles, plastic polymers, and in cars industry. The annual consumption of flame retardants is currently over 1.5 million tons [2].

The ideal flame retardant should be compatible, i.e. not alter the mechanical properties of the plastic, not change colour, have good light stability, resistant towards ageing and hydrolysis. Match and begin its thermal behavior before the thermal decomposition of plastics, not cause corrosion, not have harmful physiological effects, not emit or at least emit low levels of toxic gases and be as cheap as possible [3].

Flame-Retardants are classified into two categories: 1 - Additive flame retardants are incorporated into the polymer prior to, during, or more frequently after polymerization. [4].2Reactive flame retardants are chemically bound to material in the product. The bound chemicals are not released from products [5].

\section{Material and Methods: 1-Materials}

a. Unsaturated polyester, hardener type of Methyl Ethyl Ketone Peroxide (MEKP) imported from Industrial Chemical \& Resin Co. LTD., Kingdom of Sudia Arabia.

b. Flame-retardants; Chlorinated rubber supplied from Industries Modern Painting Company (additive I); Zeolite type $3 \mathrm{~A}$ with chlorinated rubber (1:1)(additive II); Zeolite type $4 \mathrm{~A}$ with chlorinated rubber $(1: 1)$ (additive III) \& Zeolite type 5A with chlorinated rubber (1:1) (additive IV),

*Department of Chemistry, College of Science for Women, University of Baghdad 
the three type of zeolite were laboratory prepared according to reported method $[6,7,8]$.

\section{2-Tests}

a-ASTM: D-2863:Measurement of Limiting Oxygen Index (LOI), is widely used for measuring the flammability of polymers [9].

b- ASTM: D-635: Measurement of rate of burning (A.R.B), average extent of burning (A.E.B) and average time of burning (T.B) were achieved by this method [10].

c- ASTM: D- 3014: Measurement of maximum height of flame $(\mathrm{H})$ of the burning polymer, and the amount of loss in weight of polymer as a result of combustion were done according to this test [11].

\section{3-Preparing of specimens}

The samples were prepared in the dimensions of $(130 \times 130 \times 3) \mathrm{mm}$, three sheets of unsaturated polyester were prepared for each percentage weight $(3,7,10,13 \& 15 \%)$ with the additives I, II, III, and IV.

\section{Results and Discussions:}

1-Measurement of LOI using ASTM: D-2863:

Limiting oxygen index (LOI) is defined as the minimum percentage of $\mathrm{O}_{2}$ in a mixture of (oxygen + nitrogen) that will just support flaming combustion, which is necessary for the continuation flammable of specimen for more than three minutes at least. The efficiency of I, II, III and IV additives are in the following order:

IV > III > II > I

The results are listed in table (1) and represented by fig. (1).

2-Measurement of rate of burning (R.B), using ASTM: D-635:

The results obtained from these tests showed that the rate of burning (R.B) of the unsaturated polyester resin with the additives has a continuous reduction with increasing the percentage weight of additives, as in Table (2), Fig. (2). these results indicated that, the efficiency of the additives is following the order IV> III > II > I

As in the test of LOI.

3-Measurement of maximum flame height (H) using ASTM :D-3014:

Figure (3) showed that, the maximum flame height $(\mathrm{H})$ decreased with increasing the percentage of additives (inversely proportional), as shown in Table (3).For the additive IV the flame height was $4.0 \mathrm{~cm}$ in the percentage $15 \%$

The amount of residue from the combustion of unsaturated polyester resin with additives in all percentages is higher than those of remaining material without additives, the reason is that the additives are thermally degradable and fly to the flame zone retarding the combustion.

In general, the results obtained indicated that the, additive IV the best efficiency to retarder combustion. Depending on the structure of additives, the highly effectiveness of the additive IV can be attributed to the synergistic effect of zeolite 5A with chlorinated rubber which consists of a high percentage of halogen (Chlorine $67 \%$ ) as well as thepresence of silicon, aluminum and calcium oxides account for $77.46 \%$ of the total chemical composition of the clay. Halogen-containing flame retardants are releasing halogen radicals, which react with the high energy $\mathrm{H}^{\circ}$ and ${ }^{\circ} \mathrm{OH}$ radicals which are responsible of combustion continuation of polymeric material, chlorine atoms are very efficient flame inhibitors[12].

Also the additives can promote the formation of a good carbon char residue, which can isolate heat and oxygen from flame zone to the polymeric material and as a barrier 
combustible gas degraded from the polymeric material to flame.

In addition to that, liberation of a group of non-flammable gases, e.g. $\mathrm{H}_{2} \mathrm{O}, \mathrm{CO}, \mathrm{CO}_{2}$ and carbonaceous charis responsible of the formation of compact char layer, insulating the heat transfer and can isolate combustible gas, heat and oxygen from flame zone to the polymeric material, which results in the high flame retardancy.

Table 1- Limiting Oxygen Index (LOI) of unsaturated polyester resin, with additives.

\begin{tabular}{|c|c|c|c|c|c|c|}
\hline $\begin{array}{c}\text { Additives } \\
\text { \% Types Of } \\
\text { Additives }\end{array}$ & Non & 3 & 7 & 10 & 13 & 15 \\
\cline { 2 - 7 } & 20 & 23.00 & 24.80 & 25.60 & 27.00 & 28.00 \\
\hline CR & 20 & 23.50 & 25.20 & 26.80 & 28.00 & 29.00 \\
\hline $3 \mathrm{~A}+\mathrm{CR}$ & 20 & 23.80 & 25.35 & 27.00 & 28.40 & 29.20 \\
\hline $4 \mathrm{~A}+\mathrm{CR}$ & 20 & 24.00 & 26.00 & 27.20 & 28.90 & 29.90 \\
\hline $5 \mathrm{~A}+\mathrm{CR}$ & \multicolumn{7}{|c|}{} \\
\hline
\end{tabular}

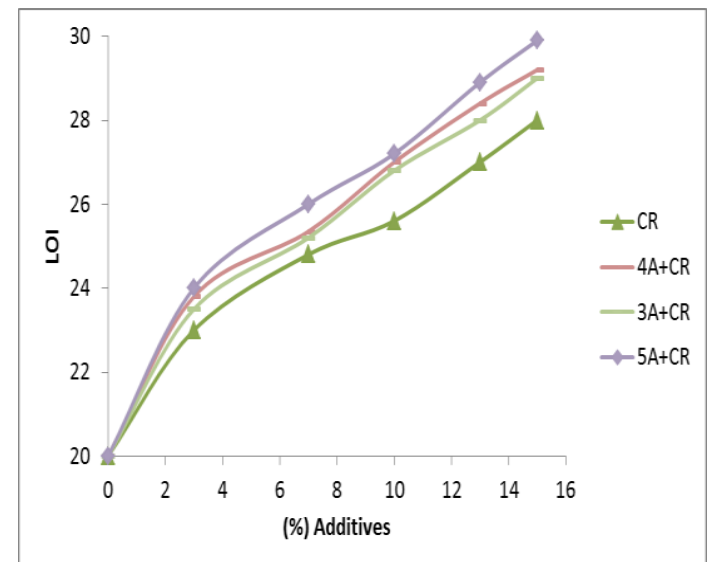

Fig.(1-1) LOI of unsaturated polyester resin with additives

Table (2): Rate of Burning, Average Extent of Burning, and Average Time of Burning for unsaturated polyester with different percentages of additive (CR) according to ASTM: D-635

\begin{tabular}{|c|c|c|c|c|c|c|}
\hline $\begin{array}{c}\text { Additives\% } \\
\text { Test }\end{array}$ & Non & $\mathbf{3}$ & $\mathbf{7}$ & $\mathbf{1 0}$ & $\mathbf{1 3}$ & $\mathbf{1 5}$ \\
\hline $\begin{array}{c}\text { R.B } \\
\text { cm/min }\end{array}$ & 1.43 & 1.23 & 1.07 & - & - & - \\
\hline AEB Cm & 10 & 10 & 10 & - & - & - \\
\hline ATB Min & 6.99 & 8.10 & 7.04 & - & - & - \\
\hline S.E & - & - & - & Yes & Yes & Yes \\
\hline N.B & - & - & - & - & Yes & Yes \\
\hline
\end{tabular}

Table (3): Rate of Burning, Average Extent of Burning, and Average Time of Burning for unsaturated polyester with different percentages of additive $(4 \mathrm{~A}+\mathrm{CR})$ according to ASTM: D-635

\begin{tabular}{|c|c|c|c|c|c|c|}
\hline $\begin{array}{c}\text { Additives\% } \\
\text { Test }\end{array}$ & Non & $\mathbf{3}$ & $\mathbf{7}$ & $\mathbf{1 0}$ & $\mathbf{1 3}$ & $\mathbf{1 5}$ \\
\hline $\begin{array}{c}\text { R.B } \\
\mathbf{c m} / \mathbf{m i n}\end{array}$ & 1.43 & 0.88 & - & - & - & - \\
\hline $\begin{array}{c}\text { AEB } \\
\text { Cm }\end{array}$ & 10 & 3.8 & - & - & - & - \\
\hline $\begin{array}{c}\text { ATB } \\
\text { Min }\end{array}$ & 6.99 & 4.31 & - & - & - & - \\
\hline S.E & - & Yes & Yes & Yes & Yes & Yes \\
\hline N.B & - & - & - & Yes & Yes & Yes \\
\hline
\end{tabular}

Table (4): Rate of Burning, Average Extent of Burning, and Average Time of Burning for unsaturated polyester with different percentages of additive $(3 A+C R)$ according to ASTM: D-635

\begin{tabular}{|c|c|c|c|c|c|c|}
\hline $\begin{array}{c}\text { Additives\% } \\
\text { Test }\end{array}$ & Non & $\mathbf{3}$ & $\mathbf{7}$ & $\mathbf{1 0}$ & $\mathbf{1 3}$ & $\mathbf{1 5}$ \\
\hline $\begin{array}{c}\text { R.B } \\
\mathbf{c m} / \mathbf{m i n}\end{array}$ & 1.43 & 0.91 & 0.80 & - & - & - \\
\hline $\begin{array}{c}\text { AEB } \\
\mathbf{C m}\end{array}$ & 10 & 10 & 4.8 & - & - & - \\
\hline $\begin{array}{c}\text { ATB } \\
\text { Min }\end{array}$ & 6.99 & 10.98 & 6.00 & - & - & - \\
\hline S.E & - & - & Yes & Yes & Yes & Yes \\
\hline N.B & - & - & - & - & Yes & Yes \\
\hline
\end{tabular}

Table (5): Rate of Burning, Average Extent of Burning, and Average Time of Burning for unsaturated polyester with different percentages of additive $(5 \mathrm{~A}+\mathrm{CR})$ according to ASTM: D-635

\begin{tabular}{|c|c|c|c|c|c|c|}
\hline $\begin{array}{c}\text { Additives \% } \\
\text { Test }\end{array}$ & Non & $\mathbf{3}$ & $\mathbf{7}$ & $\mathbf{1 0}$ & $\mathbf{1 3}$ & $\mathbf{1 5}$ \\
\hline $\begin{array}{c}\text { R.B } \\
\mathbf{c m} / \mathbf{m i n}\end{array}$ & 1.43 & 0.85 & - & - & - & - \\
\hline $\begin{array}{c}\text { AEB } \\
\text { Cm }\end{array}$ & 10 & 3.6 & - & - & - & - \\
\hline $\begin{array}{c}\text { ATB } \\
\text { Min }\end{array}$ & 6.99 & 4.23 & - & - & - & - \\
\hline S.E & - & Yes & Yes & Yes & Yes & Yes \\
\hline N.B & - & - & - & Yes & Yes & Yes \\
\hline
\end{tabular}




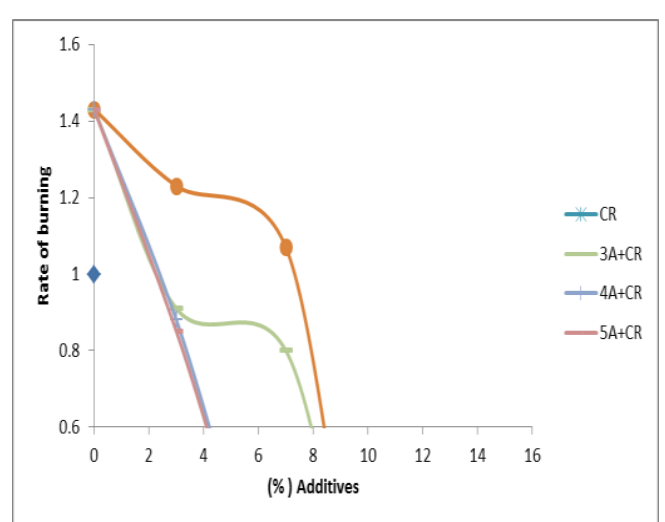

Fig. (1-2) Rate of burning for unsaturated polyester resin with additives

Table (6): The maximum height of flame (H) according to ASTM: D3014 for unsaturated polyester resin with different percentages of additive (CR).

\begin{tabular}{|c|c|c|c|c|}
\hline Nest & W1 & W2 & PWR & H \\
\hline $\mathbf{3}$ & 5.60 & 2.55 & 54.46 & 14.0 \\
\hline $\mathbf{7}$ & 6.23 & 2.64 & 57.62 & 10.5 \\
\hline $\mathbf{1 0}$ & 6.28 & 2.71 & 56.84 & 9.5 \\
\hline $\mathbf{1 3}$ & 6.31 & - & - & - \\
\hline $\mathbf{1 5}$ & 6.36 & - & - & - \\
\hline
\end{tabular}

Table (7): The maximum height of flame (H) according to ASTM: D3014 for unsaturated polyester resin with different percentages of additive (4A+CR).

\begin{tabular}{|c|c|c|c|c|}
\hline Non & W1 & W2 & PWR & H \\
\hline $\mathbf{3}$ & 5.60 & 2.55 & 54.46 & 14.0 \\
\hline $\mathbf{7}$ & 6.36 & 2.95 & 53.16 & 9.0 \\
\hline $\mathbf{1 0}$ & 6.40 & 3.15 & 50.78 & - \\
\hline $\mathbf{1 3}$ & 6.48 & - & - & - \\
\hline $\mathbf{1 5}$ & 6.55 & - & - & - \\
\hline
\end{tabular}

Table (8): The maximum height of flame (H) according to ASTM: D3014 for unsaturated polyester resin with different percentages of additive (5A+CR).

\begin{tabular}{|c|c|c|c|c|}
\hline Additives \% & W1 & W2 & PWR & H \\
\hline Non & 5.60 & 2.55 & 54.46 & 14.0 \\
\hline $\mathbf{3}$ & 6.41 & 3.21 & 49.92 & 8.0 \\
\hline $\mathbf{7}$ & 6.45 & - & - & - \\
\hline $\mathbf{1 0}$ & 6.52 & - & - & - \\
\hline $\mathbf{1 3}$ & 6.60 & - & - & - \\
\hline $\mathbf{1 5}$ & 6.63 & - & - & - \\
\hline
\end{tabular}

Table (9): The maximum height of flame (H) according to ASTM: D3014 for unsaturated polyester resin with different percentages of additive (3A+CR).

\begin{tabular}{|c|c|c|c|c|}
\hline Non & W1 & W2 & PWR & H \\
\hline $\mathbf{3}$ & 5.60 & 2.55 & 54.46 & 14.0 \\
\hline $\mathbf{7}$ & 6.32 & 2.86 & 54.47 & 9.5 \\
\hline $\mathbf{1 0}$ & 6.38 & 2.95 & 53.76 & 8.5 \\
\hline $\mathbf{1 3}$ & 6.45 & 3.11 & 51.78 & 7.0 \\
\hline $\mathbf{1 5}$ & 6.51 & - & - & - \\
\hline
\end{tabular}

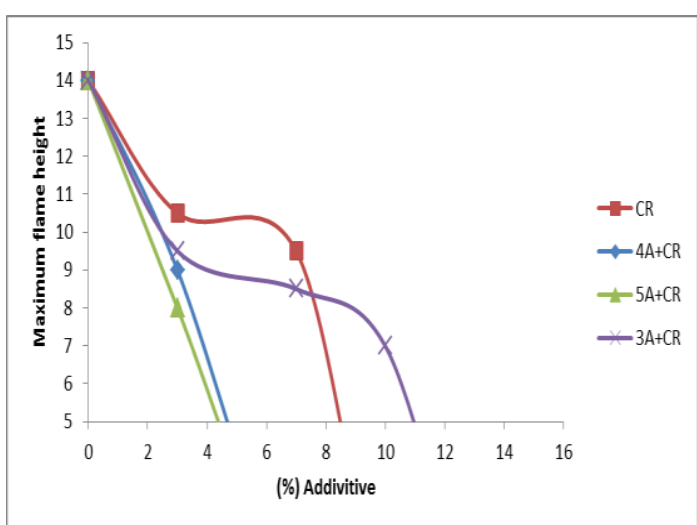

Fig. (1-3) Flame height for unsaturated polyester resin with additives

\section{Conclusion:}

The main conclusions of this work can be summarized as follows: 
The flame-retardancy efficiency of the additives I, II, III and IV appeared to follow the order:

\section{IV > III > II > I}

, The synergistic effect of zeolite 5A with chlorinated rubber and zeolite $4 \mathrm{~A}$ with chlorinated rubber gave the best results in blocking the flammability of unsaturated polyester resin comparing with the other additives., Self extinguishing (S.E) occurred at the percentage $(3 \%)$ of the additive (IV), and at the percentage $(7 \%)$ for the additives (II)., Non-burning (N.B) occurred at the percentage (10, $13 \& 15 \%)$ of the additive (IV)., The (LOI) increased with increasing the weight percentages of the additives. And the rate of burning (R.B) and the flame height $(\mathrm{H})$ decreased with increasing the weight percentages of the additives.

\section{References:}

1- A. R. Horrocks and D. Price," Fire retardant Materials", 2nd ed., CRC Press LLC, Cambridge England,2001.

2-S. N. Arju, "Use of Transition Metal Ions to Enhance Flame Retardancy of Ammonium Polyphosphate Treated Back coated Cotton Fabrics.", International Journal of Engineering \& Technology, Vol: 10 No: 03, 2010

3-S.Posner,L.Börås," Survey and Technical Assessment of Alternatives to Decabromodiphenyl Ether (decaBDE) in plastics". Report, The Swedish Chemicals Inspectorate, Stockholm,June 2005.

4-M. Harju, E. S. Heimstad, D. H.T. Sandanger, S. Posner and F. Wania,
"Current state of knowledge and monitoring requirements - Emerging "new" brominated flame retardants in flame retarded products and the environment", Statens Forurensningstilsyn, Oslo, December 2008.

5- Meeting of the California Environmental Contaminant Biomonitoring Program (CECBP) Scientific Guidance Panel (SGP) "Brominated and Chlorinated Organic Chemical Compounds Used as Flame Retardants", December 4-5, 2008

6- J. R. Ugal, K. H. Hassan, I. H. Ali, "Preparation of Type 4A Zeolite from Iraqi Kaolin:characterization and properties measurements", Journal of the Association of Arab Universities for Basic and Applied Sciences, Vol. 9, 1-8,2010.

7- N.S. Ahmed, J.R. Ugal, Iraqi Journal of Chemical and Petroleum Engineering, Vol2,No3, September 2001.

8-N.S. Majeed, M.Sc. Thesis, College of Chemical Engineering , University of Baghdad, 1999

9- Anuual Book of ASTM standard. 08-02, 1986.

10-Anuual Book of ASTM, Part 39, 1981

11-Anuual Book of ASTM part, 35, 1976 .

12- R.C. Kidder, , J.H. Troitzsch, E. Naumann , and, H.J. Roux, From Course Work Materials in New Developments and Future Trends in Europe and the United States for Fire Retardant Polymer Products, 1989. 
التأثير التأزري للزيولايت نوع (A) مع المشاط المكلور كمثبطات للهب البولي استر غير

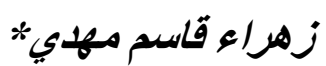
*ليل رهيف عكال

* قسم الكيمياء - كلية العلوم للبنات - جامعة بغداد

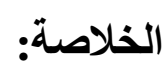

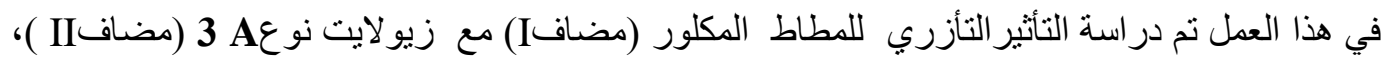

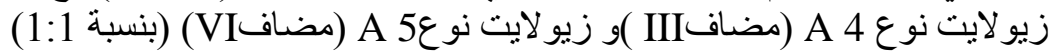

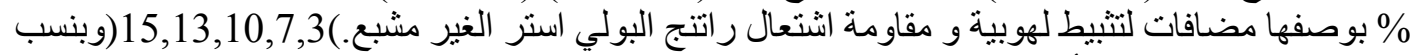

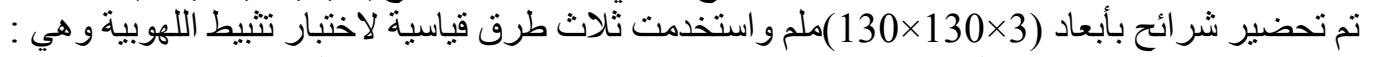

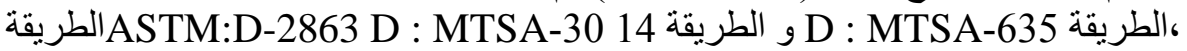
الشارت النتائج التي تم الحصول عليها الى ان جميع المضافات كانت فعالة وأن المضاف الاخير يمنلك كفاءة اعلى في تنييط لهوبية راتتج البولي استر الغير مشبع. 